\title{
DEVELOPING THE SENSE OF THE MEANING OF LIFE IN CHILDREN AND YOUTH AS A GOAL OF CREATIVE PROPHYLAXIS
}

\author{
Irena Mudrecka
}

\begin{abstract}
This article complies with the belief that in social prophylaxis it is necessary to shift the center of gravity from "fighting" pathologies and negative deviations onto forming and strengthening positive factors which protect the individual and social groups against pathologies. Formation of a constructive feeling of the meaning of life, among others through development towards higher values, is such a procedure that realizes the aims of contemporary creative prophylaxis and - at the same time - addresses the goals of rearing. Supporting emotional, cognitive and social development of the young makes it possible to develop their potentials understood as abilities, predispositions, talents, skills and competences which are a guarantee that they will find the meaning of life and make this feeling real. In a satisfying life there is no room for social pathologies.
\end{abstract}

\section{Keywords}

social pathologies, creative prophylaxis, positive prophylaxis, sense of the meaning of life, values

\section{Introduction}

The notion of social pathology, etymologically, is a combination of two words: patos, meaning 'suffering' and logos, meaning 'science/study of'. It is then possible to say, in short, that pathology is a study of suffering, while social pathology is a study of social suffering, thus being of the supra-individual character. Social pathology is defined by Szpringer (2004, p. 23) as "phenomena relating to social behavior of the individual and defined groups, as well as functioning of institutions that contradict values and principles currently accepted by the given society, like criminality, drunkenness, alcoholism, drug addiction, prostitution, pathology of organizational structures such as cliques, nepotism, incompetence, unclear division of duties and responsibility." Therefore, phenomena of social pathology are always connected with not respecting universal values, which is the source of wrong, injustice and suffering. Their range exceeds the scope of those 
traditionally described (individual pathology or group pathology). Moreover, they run over a number of levels and ranges of social evil (e.g., institutional pathology), yet are always linked to people's behaviors (Nowak \& Wysocka, 2001).

The phenomena which are counted into social pathology evidently contradict values of a given culture, since they violate social norms that safeguard the basic values such as human life, health, man's dignity, freedom, responsibility, love, truth. These values are replaced by anti-values (substitutes of values), the realization of which leads to destruction of oneself and other people. As a result, the line between good and evil becomes blurred, while the process of evaluation is disturbed as there is no unambiguous compass to indicate what things are the most important in life, what is worth accomplishing and making efforts, what brings satisfaction and the sense of fulfilment - in consequence what enables to experience happiness. Man's natural endeavors to find the meaning of life is threatened, which only winds up the spiral of social pathology. It is values that invest our lives with a sense and as regards this - the lack of the skill of evaluating causes the meaning of life to be lost or to be found in such substitutes as: alcohol, abuse of authority, power, violence, money, instant pleasures (hedonistic values), nihilism. They are, however, merely short-term substitutes which are not capable of filling in the gap of the lack of universal values. This is an open road to satisfying psychic needs at the expense of one's own health (alcohol, drugs) or at the expense of other people.

Creative prophylaxis, as a system of actions directed towards prevention of phenomena of social pathology, means such actions that aim at strengthening behaviors which are pro-social, creative and worthy of imitation. Creative prophylaxis consists in concentrating on the strong sides that each individual holds, their developmental potentials and autocreative inclinations. The goal of creative prophylaxis is to develop new desired features in the individual, which make him/her resistant to negative impacts of the environment (Mudrecka, 2012, p. 273-284). The prophylaxis understood in this way appears more and more often in the literature on the subject under the name of positive prophylaxis (Kowalski, Kania, \& Śliwa, 2018), whose aim is to equip young people with such traits and competences that make them resistant to threats and protect them against pathologies, thus ones which prepare them better to living in contemporary world in which there are increasingly more risk factors. It is undoubtedly development of a constructive feeling of the meaning of life that promotes this feature and predisposition.

\section{The sense of the meaning of life}

Recognition and understanding of oneself, other people and regularities that govern this world are meant to develop the skill of foreseeing events so that the individual should be able to take the most optimal life decisions. Effective orientation in the world is not complete, though, without holding a view on our own place in the world, what we are living for, or what reasons justify our living. Subjective understanding of the meaning of one's life is connected with the problem area of recognized values, crystallized life goals, mortality and needs. Whatever is valuable and, as a result, becomes the object of people's efforts and the source of man's motivation - is reasonable. 
Kazimierz Popielski, a follower and propagator of the ideas of Victor E. Frankl - the founder of logotheory and logotherapy - deals with considerations on ways of experiencing the meaning of life. He believes that the term "feeling" points to the fact that this notion is relativized to the subject who experiences it. The feeling of the sense of life means thus "certain general conviction of the individual, which supports their motivation and force necessary to live, make endeavors and references. It is connected with such content of life as: reflection, hope, trust, life prospects, love, good, sense. The feeling arising in their context and in connection with their content is the force that mobilizes and directs man's existence" (Popielski, 1994, p. 170). The same author links the sense of the meaning of life with the noetic, spiritual dimension of human existence, which is the effect of selecting individual fundamental goals of life that direct further actions.

The notion of the meaning of life is a construct consisting of the following three components:

- cognitive - which refers to the process of creating and investing life experiences with meanings; this is a set of views and beliefs through which the individual explains and interprets his/her own meaning of life;

- emotional - which refers to such feelings and experiences as satisfaction, content, happiness, fulfillment; realization of the meaning of life always connects with positive emotional states;

- motivational - which is linked to needs, goals and systems of values; here, the very process of selection of life goals itself is vital, as well as their carrying out; achievement of aims invests the individual's existence with a sense (Klamut, 2002, p. 25-26).

The research conducted by Porczyńska-Ciszewska (2013, p. 23) points to the fact that the sense of the meaning of life is conditioned by subjective variables and not situational ones. To the highest degree it is correlated with such personality traits as extraversion, neuroticism (negative correlation), amicability, conscientiousness, the sense of location of (internal) control and openness. Upon analyzing the paths, relations between the sense of the meaning of life and personality traits from the model of the Great Five were revealed and, additionally, the variable - Behavior Model type A (in comparison with type B). There was also found an inclination towards undertaking risk behaviors (a negative relation). On the other hand, the model does not include the sense of control location. At the same time, the author noticed a high positive statistical relation between the sense of the meaning of life and experiencing happiness. She concluded that this sense performs the function of an intermediate variable in experiencing happiness.

The meaning of life is thus a tendency which motivates man towards undertaking specific actions that invest the life with a value exceeding the very existence of man itself. This activity manifests itself in particular in the course of development and realization of psychic needs. Kazimierz Obuchowski underlines that learning about the world is of a dual nature: beside the intellectual orientation within the real world, it is indispensable to develop emotional orientation as well, since the two manners of recognizing the world are inseparably connected with each other. Therefore, apart from the cognitive need and 
one for emotional contacts, the author includes striving for the meaning of life in the group of orientational ones, as well. Moreover, he defines the need for the meaning of life as a man's personality trait which "makes it impossible for man to function properly without the existence of such values in his life activity that are or may be regarded by him as investing his life with the sense of living. This means, in practice, that his life activity is too weak in relation to the possibilities offering themselves, not directed or evaluated negatively by himself" (Obuchowski, 1983, p. 210). The author claims also that without finding one's own meaning of life, man is not capable of developing his personality to its full extent. The sense of living is a factor conditioning the motivational stability of the individual, his resistance to obstacles, satisfaction with life and becoming a better and better person. The meaning of life should be a creation of one's own reflection on himself/ herself and the reasons of it have to be clearly determined so that a chance of modifying it ought to exist along with the appearance of changes in living conditions, acquisition of new knowledge, a new understanding of the world. When the meaning of life is imposed from outside, when it results from the regulations of the role, from the system of values or a situation imposed from outside, its impact on man's fate is limited (Obuchowski, 2000, p. 282). Moreover, Obuchowski is convinced that finding the meaning of one's own life protects man from neurosis, pathologies, deviations, helplessness, objectivization. Thanks to it, man develops into a subject, an intentional being.

Katarzyna Skrzypińska has provided a synthesis of knowledge on the role played by the meaning of life by means of acknowledging its functions. Consequently, she listed the following functions:

- satisfying man's basic needs - primarily the need for safety and that for contact with others, the fulfilment of which makes development and satisfaction of higher level needs possible. This, in turn, builds and solidifies the sense of selfworth; finding the meaning of life gives rise to a subjective sense of satisfaction; - influencing the personality development - fulfilling the need for the sense of life

- makes it possible to approve of one's own actions and allows engaging in one's

- personal development, in discovering and realizing one's own possibilities and potentials;

- directing life activity - the meaning of life enables to mark out the given aim by man himself, while endeavoring to realize it invests the life with a sense, permits to reach the level of goals which are pro-social and go beyond personal ones;

- facilitating orientation in the world - recognition of the world of values and establishment of the clear personal hierarchy of values make it possible for man to choose what is the most important to him/her, in this respect - values which make life sensible and offer a 'guide post' performing an important regulatory function (Skrzypińska, 2002, p. 96-99).

The lack of the sense of the meaning of life poses a drama to human beings, since it is not only a source of negative emotional states, but also one of an existential emptiness entailing crises and psychic breakdowns, a feeling of penetrating sadness, the sense of being lost. There ensue depression, escaping into addictions and compulsions. An increase in negative emotional states gives rise to entering into interpersonal conflicts, 
not reckoning with feelings and rights of other people, thus it opens the road to criminality. It follows from the studies carried out by Jan Szałański and Paweł Nowak that "socially-maladjusted youth are characterized by a considerably lower level of the sense of the meaning of life than the young who do not display any characteristics of social maladjustment. The former are therefore exposed to existential frustration to a greater degree and - on the other hand - the symptoms of social maladjustment can partially be a consequence of this frustration" (Szałański \& Nowak, 1995, p. 68).

\section{Supporting the development of the sense of the meaning of life in the young as a goal of creative prophylaxis}

Obuchowski states that formation of the concept of oneself is a complex process and consists of three phases: identification, 'cosmic' and the mature need for the meaning of life. The phase of identification is especially significant in the process of personality development, since identifying with others (first with the parents, then with friends and members of groups which the individual is a member of) is not only a kind of fulfilling emotional contacts, but also a way of investing life with a meaning. Man's identification with somebody who seems 'reasonable' and worthy, is connected with copying superficial features and/or ways of reacting in different situations. Thus, identification enriches the repertoire of behaviors and broadens the spectrum of possibilities of solving problems as well as satisfying individual needs. In the period of adolescence, this is a particularly important mechanism and therefore identification with a reference group (subculture, group of fans) is so strong that a young person is readily capable of sacrificing his/her contacts with parents for its sake. This phase is a natural one in humans' development. Still, there are individuals who stop at this stage, which prevents them from attaining psychic maturity. Obuchowski claims further that hardships encountered in life, like divorcing of parents, illness or the necessity of coping with problems of life, accelerate exiting this phase. Problems incline towards pondering over oneself, as well as generate the beginning of making attempts to look for the sense of living in a different form (Obuchowski, 2000, p. 307).

The 'cosmic' phase is connected with searching for something that will provide the meaning of life and what exists outside man, that is in the Cosmos. A variety of philosophical conceptions are available here. They supply knowledge on the order of this world, man's place in it and his struggling against life. Power is sought for in the Cosmos, which determines the fate of man and determines his destination. Tarot, numerology or horoscopes are strongly relied on. This is an important stage in humans' development, since it facilitates formation of the Weltanschaaung and makes a form of search for one's own subjectivity. Nevertheless, stopping at this level prevents the individual from formulating long-term personal tasks and ridding of the dependence on external factors. The mature person's need for finding the meaning of life is the phase thanks to which human beings find the meaning in themselves, in the internalized values and in their own actions, hence nobody can take it away from them, steal or destroy it any longer. In this sense the need gives man the greatest feeling of safety. The mature need for the 
meaning of life results from the feeling of responsibility for one's own life and "includes the individual's contribution to what he/she exists in, what he/she is active in and what his/her future will be realized in" (Obuchowski, 2000, p. 314). It is then a way to fulfill his/ her being in the world that is constantly changing.

Therefore, the sense of the meaning of life is formed beginning with human being's birth and it is from this very moment itself that we should take care of its proper development. Comprehending the dynamics of the development of the need for the meaning of life, the young have to be supported by satisfying the conditions that are indispensable for their development. At the first stage of development, each child must have the basic need for safety and emotional contacts satisfied by its parents or a permanent guardian in order that it could identify with them. Then, it needs taking care of that each child should be a member of a peer group who are carriers of accepted social norms. A peer group performs a significant socializing function by impacting the consciousness-moral sphere of its members, which follows through exchanging opinions and establishing group-based norms. Inside their groups, the members have the possibility of fulfilling their relevant psychic needs (acceptance, security, belonging, social appreciation), as well as verifying the experience derived from their homes. It is not until the individual 'grows out of' the peer group which he/she identifies himself/herself with, that he/ she can find the meaning of life in ideologies, religions or other values existing in the Cosmos, that is outside himself/herself. And this indeed is what opens to the person his/ her individual path to further search for values which will become interiorized and will serve as indicators of the mature person's meaning of life.

Barbara Kaja mentions possible influences which favor formation of the sense of the meaning of life in children. They are listed below as follows:

- teaching values which invest life with a meaning through elevating contacts with worthy and influential people and also co-experiencing events. The person of the teacher, because of who he/she is and what he/she does (his/her own system of values), is a model of giving meanings to objects, ideas, people in everyday life. Thus, he/she forms an offer, but it is the young who choose these values which suit them by attributing individual significance to them;

- shaping biographical competences - discovering the meaning of life requires subjective orientation in one's own life, which means that the young one must possess, among others, knowledge about himself/herself, about the world, as well as the skills of biographical thinking and managing one's own life and development;

- the model of partner-based formation of life and meaning-generating values the teacher is a moderator and not a person who knows better what is good and what is bad; the young are not treated as less competent; conversation is given priority to instruction;

- the model of creative hypotheses and their critique - the model of guesses and refutations; with the use of Socratic dialogue the young themselves arrive at finding solutions to moral, civilization or religious problems (Kaja, 2001, p. 104-107). 
The sense of the meaning of life is a subjectively felt, positive psychic state connected with the awareness of making values real, through which an individual goal of life is realized. In its content, this goal holds the highest value (higher than life itself) to the given human being. Hence the strong inner need for its carrying out and the agreement to subordinate to it many actions that are defined and are extended over time and by means of this - over the whole of one's life. Subjecting these actions to a life goal makes a meaning-generating influence on the life, that is all these actions become reasonable (take on a value as a means indispensable for realization of the main aim).

The sense of the meaning of life, together with the state of happiness accompanying it, does not depend on - as it might seem - prosperity. In the "Introduction" to Psychologia pozytywna [Positive Psychology], Janusz Czapiński stated that "along with a rise in affluence [...] the epidemics of depression in young generations expands, the number of divorces grows, the social capital of mutual trust diminishes, materialistic and consumerism-oriented attitudes grow stronger, the threat of sexual harassment of children increases, customs deteriorate, the number of suicides and crime against life and health goes up," while "people feel more and more clearly the lack of 'instruction' how to live in order to preserve sound senses and be able to die with the conviction that they did not waste the chance which they were given on the day of their birth, that they did what they were supposed to in the best way they could, that they did not take the wrong way, that their stay on Earth had a deep sense" (Czapiński, 2004, p. 7).

The significance of the sense of meaning in the life of man can hardly be overestimated, since man's psychic condition largely depends on it. Moreover, it also conditions the kind of emotions that are to be dominant in man's life, the skill of coping with adversities of fate, experiencing satisfaction and the general content with one's own life. The process of rearing of young generations should thus be directed at supporting children and youth in finding the meaning of their lives and in preparing them to living with the recognition of its significance. The latter is defined as a value and, therefore, as rearing towards values. This is the type of rearing expected to guarantee that the young will find right values which will invest their lives with a meaning. Values, however, exist solely inside human beings, and outside them - become an intellectual construct. Therefore, values need to be experienced, which necessitates "experiencing determined impressions/experiences by the subject, mainly via active participation and engagement, as recognition by means of a personal and direct contact" (Ostrowska, 2001, p. 54). Consequently, without contacts with other human beings who are carriers of positive values there is no rearing towards values. Socially maladjusted people who suffer from an existential emptiness, only too often used to experience negative emotions in their contacts with adults, including aggression, violence, derision, psychic oppression, humiliation - that is effects of having been perceived not as a value themselves and almost exclusively having been exposed to anti-values.

It can be concluded that it is personality models that are of paramount importance to discovering the meaning of life, since a young person, who is growing up, has an opportunity to observe them on his/her path of life. Another relevant factor of great 
significance here is the quality of the experiences in interpersonal contacts, during which these values turn into reality.

Values represent personally and socially desired versions of individual needs and social requirements. Research proves that adolescents do not differ in any basic way from the general population of the young as regards the hierarchy of accepted values, whereas the outlined differences are primarily connected with the selection of means to attain them (Ostrowska, 2008). That is why the adolescent must be aided in the process of mentalization of their own psychic needs and in discovering such modes of their fulfillment that do not contradict social requirements. A condition behind the positive development is balancing and achieving a consensus between values that serve the needs of one's own ' $I$ ' and those of others. Here, a barrier is posed by the fact that the majority of minors are characterized by egocentric motivation, which results in that only values relating to the well-being of the individual are taken care of at the expense of the social ones. Limiting the egoism and teaching the young the skill of decentration have for a long time now been the goal of resocialization-related actions.

It also needs emphasizing that it is indispensable to support the emotional, cognitive and social development of the young via making it possible for them to develop their potentials which are understood as abilities, predispositions, talents, skills and social competences. Then, the probability is greatly increased that the sense of the meaning of life in children and youth, and next in adults, will be characterized by proper dynamics of development and, consequently, will become a source of psychic well-being.

\section{Conclusions}

The essence of humans' proper functioning is investing our existence with a meaning, a sense - including the meaning of our own lives. It is this construct and the role of the meaning of life that our resistance to hardships and difficulties which cross the paths of our lives depend on. When we know what we really want, we treat these obstacles as challenges. On the other hand, man who does not know what he wants and what he is living for limits himself to pleasures and resorts to escaping from problems and avoiding discomforts.

Thus, the individual system of values performs a vital function in our lives, since it allows obtaining orientation in the external and internal worlds, as well as permits to differentiate between good and evil, between things that are precious and those which pose a threat to us. Individual values are indispensable to understand the reality and to execute rational actions in it. They mark out our path of life. The values which are internalized and acknowledged by the individual in this sense make the person resistant to negative risk factors, since they set a clear direction of our activity, bringing satisfaction through inner gratification. It is in them where the individual can find the meaning of his/her life. Values are deciding about the power of motivation to act in order to implement the meaning of life, as well as make the individual fight for what he/she desires. Additionally, they generate mechanisms of self-control by triggering off moral feelings in the situation in which the individual departs from his/her values. 
Educating towards acquisition of values and formation of the constructive feeling of finding the meaning of life in young generations is such a rearing-prophylactic activity that guards the young against participating in various pathological phenomena in the individual and social dimensions (Cekiera, 2001). However, regarding this delicate matter, adults cannot impose anything on the young; they can only offer, indicate, facilitate, activate, etc. Concluding, I would like to recall the well-known statement of Cekiera (1993) that development towards higher values, ones that invest people's lives with the meaning, is the highest form of prophylaxis, since this is a shield defending the young generation against deviations, pathologies, illnesses and all sorts of threats to the development.

\section{References}

Cekiera, C. (1993). Psychoprofilaktyka uzależnień oraz terapia i resocjalizacja osób uzależnionych. Metody, programy, modele, ośrodki, zakłady, wspólnoty. Lublin: Wydawn. Tow. Naukowego Katolickiego Uniwersytetu Lubelskiego.

Cekiera, C. (2001). Rozwój ku wyższym wartościom profilaktyką przestępczości. In B. Urban, Dewiacje wśród młodzieży. Uwarunkowania i profilaktyka. Kraków: Wydaw. Uniwersytetu Jagielońskiego.

Chałas, K. (2007). Problem patologii społecznej-dezintegracja świata wartości-implikacje dla pedagogiki. In S. Badora, \& R. Stojecka-Zuber, Pedagogika wobec problemów opieki i resocjalizacji. Tarnobrzeg: Państwowa Wyższa Szkoła Zawodowa im. prof. Stanisława Tarnowskiego.

Czapiński, J. (2004). Wstęp. In J. Czapiński, Psychologia pozytywna. Nauka o szczęściu, zdrowiu, sile i cnotach człowieka. Warszawa: Wydaw. Naukowe PWN.

Dąbrowski, K. (1996). W poszukiwaniu zdrowia psychicznego. Warszawa: Wydaw. Naukowe PWN.

Kaja, B. (2001). Problemy psychologii wychowania. Teoria i praktyka. Bydgoszcz: Wydaw. Uczelniane Akademii Bydgoskiej im. Kazimierza Wielkiego.

Klamut, R. (2002). Cel - czas - sens życia. Lublin: Towarzystwo Naukowe KUL.

Kowalski, M., Kania, S., \& Śliwa, S. (2018). W kierunku konserwacji zdrowia - profilaktyka pozytywna. In Profilaktyka społeczna - edukacja - zdrowie. Twórcze wiązanie teorii i praktyki. Zielona Góra: Oficyna Wydawnicza Uniwersytetu Zielonogórskiego. 
Mudrecka, I. (2012). Kształtowanie poczucia odpowiedzialności pozytywnej u dzieci i młodzieży jako cel profilaktyki kreatywnej. In B. Urban, \& M. Konopczyński, Profilaktyka i probacja w środowisku lokalnym. Kraków: Wydawnictwo Uniwersytetu Jagiellońskiego.

Nowak, A., \& Wysocka, E. (2001). Problemy i zagrożenia społeczne we współczesnym świecie. Elementy patologii społecznej i kryminologii. Katowice: "Śląsk".

Obuchowski, K. (1983). Psychologia dążeń ludzkich. Warszawa: Państwowe Wydawnictwo Naukowe.

Obuchowski, K. (2000). Galaktyka potrzeb. Psychologia dążeń ludzkich. Poznań: Wydawnictwo Zysk i S-ka.

Ostrowska, U. (2001). Doświadczanie wartości a sens życia. In A. M. de Tchorzewski, \& P. Zwierzchowski, Sens życia - sens wychowania. Bydgoszcz: Wydawnictwo WERS.

Ostrowska, K. (2008). Psychologia resocjalizacyjna. W kierunku nowej specjalności psychologii. Warszawa: Fraszka Edukacyjna.

Popielski, K. (1994). Noetyczny wymiar osobowości. Psychologiczna analiza poczucia sensu życia. Lublin: Redakcja Wydawnictw KUL.

Porczyńska-Ciszewska, A. (2013). Cechy osobowości a doświadczenie szczęścia i poczucia sensu życia. Katowice: Wydawnictwo Uniwersytetu Śląskiego.

Skrzypińska, K. (2002). Pogląd na świat a poczucie sensu i zadowolenia z życia. Kraków: Oficyna Wydawnicza Impuls.

Szałański, J., \& Nowak, P. (1995). Poczucie sensu życia u młodzieży niedostosowanej społecznie. In T. Sołtysiak, Zjawiska patologii społecznej. Uwarunkowania, profilaktyka, rozmiary, prognozy. Bydgoszcz: Wydawnictwo Uczelniane WSP.

Szpringer, M. (2004). Profilaktyka społeczna. Rodzina, szkoła, środowisko lokalne. Kielce: Wydaw. Akademii Świętokrzyskiej.

\section{Author}

dr hab. Irena Mudrecka, prof. UO

Faculty of Social Sciences, University of Opole

ul. Oleska 48, 45-052 Opole, Poland

irena.mudrecka@uni.opole.pl 